\title{
"Methodology of complex estimation level of socio-ecological and economic development of industrial regions of Ukraine"
}

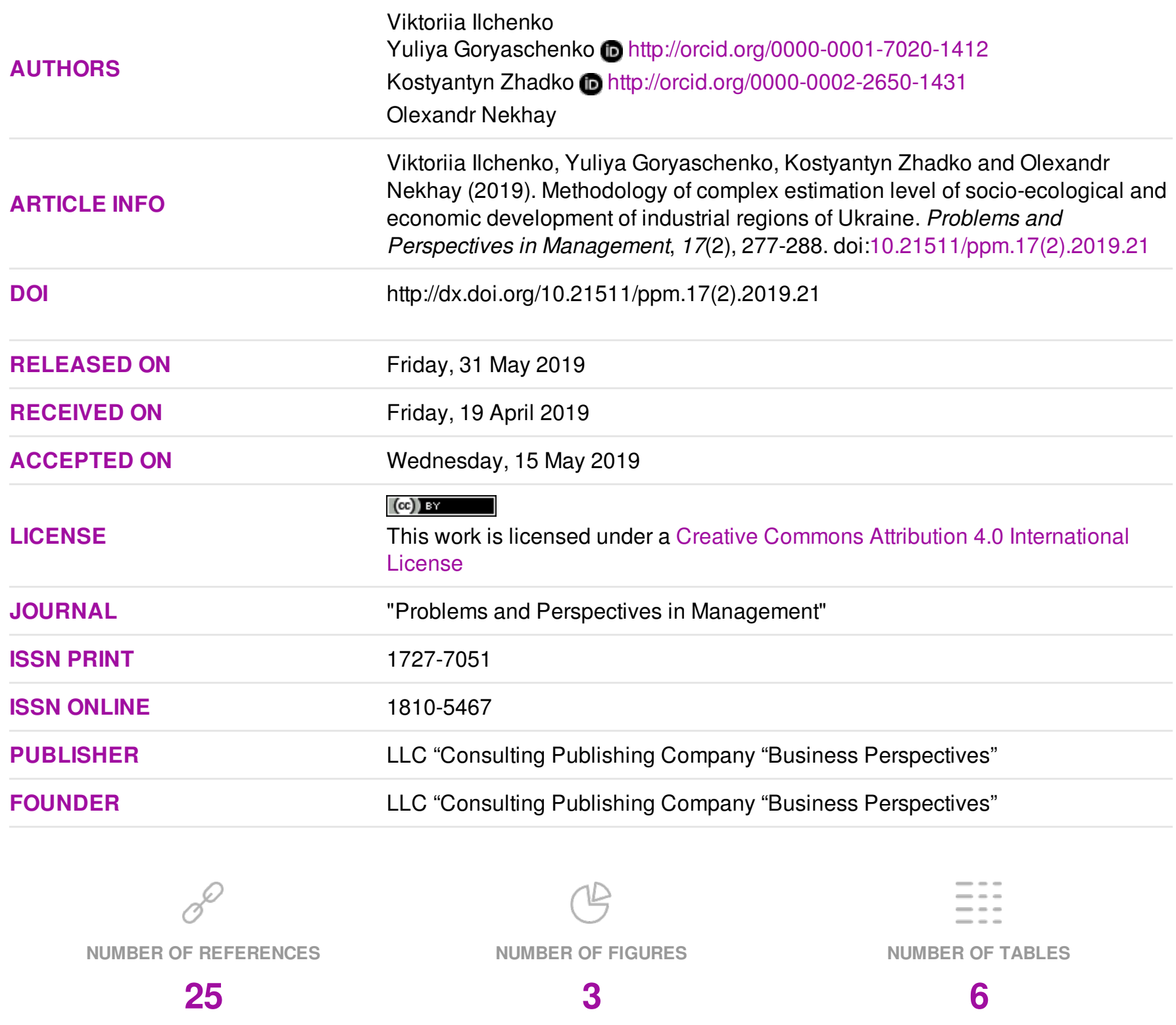

(C) The author(s) 2022. This publication is an open access article. 


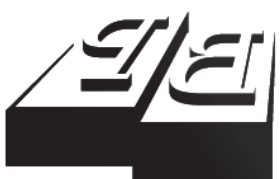

BUSINESS PERSPECTIVES

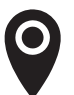

LLC "CPC "Business Perspectives" Hryhorii Skovoroda lane, 10, Sumy, 40022, Ukraine

www.businessperspectives.org

Received on: $19^{\text {th }}$ of April, 2019 Accepted on: $15^{\text {th }}$ of May, 2019

(c) Viktoriia Ilchenko, Yuliya Goryaschenko, Kostyantyn Zhadko, Olexandr Nekhay, 2019

Viktoriia Ilchenko, Ph.D. (Economics), Associate Professor of the Department of Entrepreneurship and Economy of Enterprises, University of Customs and Finance, Ukraine.

Yuliya Goryaschenko, Ph.D. (Economics), Associate Professor of the Department of Entrepreneurship and Economy of Enterprises,

University of Customs and Finance, Ukraine.

Kostyantyn Zhadko, D.Sc. (Economics), Head of the Department of Entrepreneurship and Economy of Enterprises, University of Customs and Finance, Ukraine.

Olexandr Nekhay, D.Sc. (Economics) Professor of the Departament of Economics, University Loyola Andalusia, Sevilla, Spain.

\section{(c) (i)}

This is an Open Access article, distributed under the terms of the Creative Commons Attribution 4.0 International license, which permits unrestricted re-use, distribution, and reproduction in any medium, provided the original work is properly cited.
Viktoriia Ilchenko (Ukraine), Yuliya Goryaschenko (Ukraine), Kostyantyn Zhadko (Ukraine), Olexandr Nekhay (Spain)

\section{METHODOLOGY OF COMPLEX ESTIMATION LEVEL OF SOCIO- ECOLOGICAL AND ECONOMIC DEVELOPMENT OF INDUSTRIAL REGIONS OF UKRAINE}

\begin{abstract}
The article is devoted to a comprehensive assessment and improvement of the level of regional development on the basis of determining the effectiveness of the mechanism of sustainable development of the region, developing methodical principles for the formation of regional and local strategies for ensuring sustainable development.

The purpose is to substantiate the methodology and means of integral assessment to implement the principle of equalization of sustainable development of regions in the aspect of information and innovation support by means of theories of social development, systems, clustering of the economy and economic information theory.

A methodological approach was proposed for assessing the level and trends of sustainable development of the region, based on the analysis of declarations, program and final documents of UN conferences on economic, social and environmental issues. The approach is based on the use of an integral index whose evaluation and analysis results can be used to solve problems and are implemented in the process of making sound management decisions. This approach made it possible to formulate, by means of factor analysis, a refined system of indicators that characterize economic, social and environmental sustainability parameters.
\end{abstract}

The typical groups of industrial regions of Ukraine were identified and the level of socio-ecological and economic development was assessed. This made it possible, based on the procedures for reducing the dimension and constructing generalized indicators, to calculate the rating for each calculated integral indicator as a generalized estimate. The calculations that have been carried out make it possible to determine the trends of sustainable development of individual regions on the factors of development and to justify promising directions for effective growth and negative trends, which require the greatest attention from the state authorities and local self-government bodies.

\section{Keywords}

JEL Classification sustainable development of the region, indices, indicators, assessment of the level of regional development balance, Goals of Sustainable Development, quality of life

O18, R13, R58

\section{INTRODUCTION}

The formation of an effective system for performing quantitative and qualitative evaluation is an important problem in the implementation of the concept of sustainable development. Its main requirements are information completeness and the adequacy of the presentation of the interrelated triad of components of sustainable development. The imbalance of the social, economic and environmental components is a major cause of Ukraine's failure to achieve such development.

The effectiveness of management of sustainable development of the country can be evaluated by a system of indicators that reflect some 
aspects of development in its conceptual sense, reflect the trends of the region and the impact of various factors on sustainability. Only with the help of the development of industry and social production the country will not be able to achieve a rise. It is necessary to simultaneously take care of the economy, social component and the environment.

A general vision of the new development benchmarks for 2030 and 17 Sustainable Development Goals was provided at the UN Development Summit for the post-2015 period. Ukraine has to implement new programs and projects that in practice will ensure macroeconomic stability, ecological balance and social cohesion at the state, regional and local levels.

Monitoring the achievement of the objectives of sustainable development, management of this process, decision-making process, evaluation of the effectiveness of the means used and the level of achievement of the goals required monitoring of sustainable development of society.

In recent years, significant work in the field of development of indicators has been carried out by a number of teams at the local, regional and global levels as sustainable development in general, as well as its individual aspects. Despite a significant number of researches, to some extent, outstanding issues related to the assessment of sustainable development at the regional and local levels remain unsolved.

\section{LITERATURE REVIEW}

Many of the world's leading organizations are engaged in the development of sustainability indicators for environmental and economic development. They annually report in their documents: The Delegation for Political Coordination and Sustainable Development of the United Nations (Sustainable Development Goals: Ukraine, 2017), UNEP (Frontiers 2018/19: Emerging Issues of the Environmental Concern, 2018), World Bank (World Bank Annual Report, 2018)), The Organization for Economic Cooperation and Development (OECD) (Green growth and sustainable development: report, 2018), the European Commission (Energy union and climate, 2018), the Committee on Environmental Modeling (ISEM), the Committee from the Environmental (Ecologic) Indices (ISEI), the Scientific Committee on Environmental Issues (SCOPE) (Education for Sustainable Development: National Report (2016)), International Institute for Sustainable Development (IISD), Socio-Economic Council (SER) (Development of Sustainable Development, 2011) and others.

Despite a large number of methodological approaches used to assess sustainable regional development, there is no systematic approach to assessing such a complex phenomenon. Therefore, the development of an integrated structural meth- odology that objectively determines the problems of sustainable development of the regions of the country, the choice and justification of the goals and strategic directions for its achievement (Ilchenko, 2013) is urgently needed.

Among the whole set of indicators, only such indicators (GRP per capita and degree of depreciation of fixed assets) are relative. All other indicators are absolute, which express the size (volume) of the quantitative characteristics of the phenomena under study in certain units of measurement. In this regard, the ranking of regions of Ukraine in terms of sustainable development cannot be considered correct.

The application of the relative indexes for the calculation of the integral index is important, as evidenced in the work of Y. Korol, by calculations of the level of sustainable development for the Polish voivodeships. The methodological basis of this study is also an assessment of the economic, social and environmental components. But for their characteristics, relative indicators are used, for example, to assess the scientific and technical component: the cost of innovation in industry per capita, the cost of research per inhabitant (Indicators of Sustainable Development, UN Pulpation, 1996). In compiling the ranking of regions in Ukraine, the following indicators were used to assess the level of innovation: the volume of innovation 
products (thousand UAH), the development of new types of products in industry (units), the introduction of advanced technological processes in industry (units) (Zgurovsky, 2009).

An equally important problem of the existing methodology for calculating the integral indicator of sustainable development of the region is to determine the weighting factor for each parameter on the basis of the volume of revenues in terms of money from one or another sphere of activity, as well as applying for the Pareto principle indicator (ratio 20:80) or 1:1:3, depending on the importance and number of components (Zgurovsky, 2009). At the same time, despite the fact that the value of the calculated weighting factors on a monetary expression reflects a certain imbalance in policy categories (Basic needs - 27.0\%, Entrepreneurship - 57.5\%, Labor market - 13.0\%, Innovation-investment opportunities $-2.5 \%$ ), the authors of the methodology for assessing the level of sustainable development of the regions of Ukraine consider these categories of policy equally important for the development of the administrative-territorial unit, and therefore accept the same weighted coefficients. Such an approach distorts the results of calculations and conclusions regarding interregional comparisons, because in different regions, the influence of key factors of socio-economic development can vary considerably.

\section{METHODOLOGY}

The methodology for measuring sustainable development involves the calculation of the corresponding index in the space of three dimensions: economic, environmental and socio-institutional. In this case, institutional development studies are carried out mainly in the social aspect, and its level is assessed taking into account the indicators of political consciousness of citizens, the influence of religious institutions and the effectiveness of state power. However, the institutionalization of sustainable development should envisage improvement of regulatory and legal regulation of organizational support for optimizing the social, economic and environmental components of the region.

Various indicators are used for the purpose of interregional comparisons of quantitative and qual- itative assessments of development, identification of the main factors influencing the change in the structure of the economy of different scale areas, processes characterizing disproportions and their dynamics, classification of countries and regions by the level of development.

Their spectrum has grown significantly with an increase in the number of development models, but the main economic and social indicators remain constantly in demand. The unification of various development indicators is facilitated by the work of international institutions: the United Nations and its programs, the World Bank, the Organization for Economic Cooperation and Development (OECD), the International Monetary Fund. The European Union (Grechko, Lisovsky, Romanyuk, \& Rudenko, 2015) can be considered as the source of standards for the harmonization of indicators related to development.

The information of various international rating agencies as independent sources for measuring the quality of the regional environment is increasingly being used in the assessment of regional development. The practice of monitoring regional ratings is gradually being applied in Ukraine. In particular, the Foundation for Effective Governance has published the 2007 Index of Competitiveness of Regions (Towards Economic Growth and Prosperity, 2012). The value of such a study is based on the methodology of calculating the national competitiveness index to analyze the dynamics of the economic development of the separate region in comparison with other regions, as well as with 144 countries of the world. The index is calculated using the methodology used by the World Economic Forum.

The Institute of Geography of the National Academy of Sciences of Ukraine has developed its own integral index of developmental balance, which reflects the economic-geographical aspects of the development balance. Its application makes it possible to compare the general level of balance of development of individual countries and regions, to analyze the factors that contribute or hinder the achievement of a balanced development within each of the studied areas. On this basis, it is possible to develop a system of measures on the strategy and tactics of the transition to sus- 
tainable (balanced) development of the specified countries or regions and to determine the priority tasks of implementation and provision of the corresponding policy. Based on the use of the index, the integral index of developmental balance for the countries of the world and regions of Ukraine was calculated (Lisovsky, 2009).

The Institute for Applied Systems Analysis of the National Academy of Sciences of Ukraine and the Ministry of Education of Ukraine in 2005-2007 developed a metric for measuring sustainable development processes (MSSD) in the context of economic, environmental and social components (Sadovenko, Maslovska, Sereda, \& Timochko, 2011).

Indices and approaches used differ from those proposed by the United Nations Commission on Sustainable Development. However, they reflect the principled approach to the relationship of its main components (economic, environmental, social and institutional).

Ukraine, with all the key indicators and indicators of quality of life within sustainable development, is significantly inferior not only to world leaders, but also to the majority of post-socialist countries. Today, given the state of social development, it is not really defined with the strategy of its development. Reforms in the economy, education, innovation or other spheres will not yield the desired results under such conditions.

The Institute of Applied Systems Analysis of the National Academy of Sciences of Ukraine in 2009, on the basis of the developed metric, analyzed the regions of Ukraine from the standpoint of sustainable development on the main three dimensions. The analysis was performed on the basis of the developed system of indicators that allow to control the goals of sustainable development, to make decisions, to evaluate the effectiveness of the means used and to achieve the goals set (Sadovenko, Maslovska, Sereda, \& Timochko, 2011).

The Institute for Applied Systems Analysis of the National Academy of Science of Ukraine and the Ministry of Education of Ukraine in 2014 improved the methodology of quantitative assessment of regional development processes and analysis of the obtained integrated assessments from the stand- point of the concept of sustainable development. It is important that the assessment of the efforts of the regions of Ukraine to achieve sustainability is carried out not only on the basis of observance of the balance of economic, environmental and social dimensions of development, but also in conjunction with the analysis of aspects of the safety of human life. Information about the ranking of regions of Ukraine in sections of quality and safety components of life is contained in the 2013 report.

The methodology of assessment and analysis of sustainable development includes a model of sustainable development. It is an interdisciplinary generalization of models known in the natural, economic and social sciences.

\section{RESULTS OF RESEARCH AND DEVELOPMENT OF METHODICALAPPROACHES TO ANALYSIS, ESTIMATION AND FORECASTING OF PARAMETERS OF SUSTAINABLE DEVELOPMENT OF THE REGION}

The methodology of a comprehensive assessment of the level of socio-ecological and economic development of industrial regions was proposed based on the analysis and synthesis of existing methodological approaches to assessing the level of development of the region, which is based on comparing the conditions and development outcomes of a set of features against the background of the corresponding averages.

Based on the data of the State Statistics Service of Ukraine and the Department of Statistics in the regions that characterize the level of economic, social and environmental development of the leading industrial regions of Ukraine in 2012-2018, among the sets of the initial statistical indicators, the method of factor analysis was used to select significant economic, social and environmental indicators (Table 1). 
Table 1. Key indicators of sustainable development of industrial regions

Source: Developed by the authors.

\begin{tabular}{|c|c|c|}
\hline $\begin{array}{l}\text { Components of } \\
\text { sustainable development }\end{array}$ & Indexes & Symbols \\
\hline \multirow{12}{*}{ Economic } & 1. Economic & $x$ \\
\hline & 1.1. GRP per (per 1 person) & $x_{1 \ldots}$ \\
\hline & 1.2. Retail commodity turnover is per year (per 1 person) & $x_{2}$ \\
\hline & 1.3. Amount of enterprises per year (per 1 person) & $x_{3}$ \\
\hline & 1.4. Volume of the realized products, UAH (per 1 person) & $x_{4}$ \\
\hline & 1.5. Amount of the concerned workers is per enterprises (thousand people) & $x_{5}$ \\
\hline & 1.6. Charges are per personnel on enterprises, UAH (per 1 person) & $x_{6}$ \\
\hline & 1.7. Capital investments, UAH (per 1 person) & $x_{7}$ \\
\hline & 1.8. Indexes of agricultural produce, $\%$ to previous year & $x_{8}$ \\
\hline & 1.9. Indexes of building products, $\%$ to previous year & $x_{9}$ \\
\hline & 1.10. Indexes of industrial products, \% to previous year & $\mathrm{x}_{10}$ \\
\hline & 1.11. Profits of population, UAH (per 1 person) & $x_{11 \ldots}$ \\
\hline \multirow{8}{*}{ Socio-ecological } & 2. Social and ecological & u \\
\hline & 2.1. Average monthly salary, UAH (per 1 person) & $u_{1 \ldots}$ \\
\hline & 2.2. Concerned population (thousand persons) & $u_{2}$ \\
\hline & 2.3. Unemployed population (thousand persons) & $u_{3}$ \\
\hline & 2.4. Morbidity of population (per 1 person) & $u_{4}$ \\
\hline & 2.5. Extraits of contaminents (tons is per 1 person) & $u_{5}$ \\
\hline & 2.6. General volume of wastes (tons is per 1 person) & $u_{6}$ \\
\hline & $\begin{array}{l}\text { 2.7. Extraits of contaminents are in atmospheric air from the stationary sources of } \\
\text { contamination (tons is per } 1 \text { person) }\end{array}$ & $u_{7}$ \\
\hline
\end{tabular}

In order to construct a generalized indicator of socio-ecological and economic development of the region of Ukraine, the method of the main components was used for selected aspects.

The necessary measurement procedure is the preliminary unification of the selected output indicators, that is, the application of such a transformation to them, which will all be measured on the $\mathrm{N}$-scale scale. At the same time, the zero value of the transformed indicator will correspond to the lowest level of the region, and the maximum value of $N$ is the highest. Such unification will ensure the comparability and comparability of the existing information base.

For indicator-stimulants, the value of the corresponding unified variable was calculated by the formula:

$$
v_{i r j}=\frac{\tilde{v}_{i r j}-\tilde{v}_{r j \min }}{\tilde{v}_{r j \max }-\tilde{v}_{r j \min }} \cdot N,
$$

where $v_{i r j}-i$-th value of $j$-th source of compatible index of the aspect of development $x_{r j}\left(i=\overline{1, n}, r=\overline{1,3}, j=\overline{1, m_{r}}\right), N$ - amount of supervisions on an initial index $x_{r j}, m_{r}-$ amount of initial indexes raspect of development that is examined, $\tilde{x}_{i r j}-i$-th values of $j$-th source of not unified index $r$-th aspect of development $\tilde{x}_{r j}, \quad \tilde{x}_{r j \min }-$ minimum value of the $j$-th source of unimproved indicator of the $r$-th aspect of development $\tilde{x}_{r j}, \tilde{x}_{r j \max }$ - maximum value of the $j$-th source of non-viable index of $r$-th aspect of development $\tilde{x}_{r j}$.

The calculation of the integral index $Y_{r}$ $(r=\overline{1,18})$, which characterizes certain aspects of development, was carried out according to the formula:

$$
Y_{r}=\sum_{j=1}^{m_{r}} w_{r j} X_{r j}
$$

where $w_{r j}$ - the weight with which the $j$-th indicator of the $r$-th aspect of development is taken into account in the calculation of the integral indicator.

The construction of an integral index of a particular aspect of development was carried out using the method of factor analysis, called the modified main component method. Weighted coefficients $w_{r j}$ were calculated using the modified main component method. 
After the initial value of compatible indexes of some aspect of development $X_{1}, X_{2} \ldots, X_{m}$, the standardized values of these indexes $X_{1}^{*}, X_{2}^{*} \ldots$, $X_{m}^{*}$ are calculated, but the matrix $\tilde{O}^{*}$ of the standardized values of initial factors and matrix $R$ of pair correlations are built:

$$
R=\frac{1}{n} X^{* T} X^{*}
$$

For the calculation of the first main component $F_{1}=l_{1} X^{*}$, an optimization task got untied:

$$
\left\{\begin{array}{l}
D\left(l_{1} X^{*}\right) \rightarrow \max _{l_{1}} \\
l_{1} l_{1}^{T}=1
\end{array}\right.
$$

The system of equalizations for determination $l_{1}$ looks like:

$$
\left(R-\lambda_{1} I_{m}\right) \cdot l_{1}^{T}=0
$$

where $\lambda_{1}-$ most own value of matrix $R$ that is the decision of characteristic equalization $\left|R-\lambda I_{m}\right|=0$.

Here $I_{m}$ is a single matrix of dimension of $m$.

Thus, the first main component $F_{1}$ is calculated as linear combination:

$$
F_{1}\left(X^{*}\right)=l_{1} X^{*}
$$

where $l_{1}$ - own vector of matrix $R$ that answers the most own number $\lambda_{1}$.

As a measure of informing of the first main component $F_{1}$ part of $k$ of total dispersion of this component is determined in general dispersion of initial indexes:

$$
k=\frac{D\left(F_{1}\right)}{D\left(X_{1}^{*}\right)+\ldots+D\left(X_{m}^{*}\right)} .
$$

If $D\left(F_{1}\right)=\lambda_{1}, D\left(X_{1}^{*}\right)=\ldots=D\left(X_{m}^{*}\right)=1$, then the criterion of informing $k$ can be presented in a kind:

$$
k=\frac{\lambda_{1}}{m} .
$$

The area of nonoperability of only scalar indicator of some aspect of development is determined by inequality:

$$
k<k^{*} \text {. }
$$

According to the method of the modified main component, in the calculations using formula (2), the squares of the components $w_{r j} j$ of their own vector $l_{1}$ of the covariance matrix of variables $X_{1}, X_{2} \ldots, X_{m}$.

The calculation of generalized development indicators in 2012-2018 was carried out using the software statistical package SPSS. It was accepted that $N=10$. It should be noted that during the calculations with the help of the method of the modified first main component, the dispersion, which is explained by the first main component for all aspects of the development considered, was more than $50 \%$, that is, in all cases, the criterion of the method performance was performed.

The calculation of the total dispersion explained by the first main component for constructing a component matrix on the aspect of economic development is given below (Table 2).

The following is a calculation of the total dispersion, which is explained by the first main component for constructing a component matrix on the aspect of social and environmental development (Table 4).

The integral index of economic development $X_{r}^{(I)}$ is calculated according to the method of the modified main component.

The most stable positions of the Dnipropetrovsk region have been observed for seven years in terms of economic development. In 2018, the second place is the Poltava region, the third Zaporizhzhia, the fourth and fifth, respectively Kharkiv and Sumy.

Based on the procedures for reducing the dimension and constructing generalized indicators, the rating for each calculated integral indicator is calculated as a generalized estimate. The integral indicator of socio-ecological development $Y_{r}^{(1)}$ is calculated according to the method of modified main component. It is clear from the calculations 
Table 2. Total variance explained

Source: Calculated by the authors on the basis of data from the Main Directorates of Statistics in Dnipropetrovsk, Zaporizhzhia, Poltava, Sumy, Kharkiv regions (n.d.).

\begin{tabular}{|c|c|c|c|c|c|c|}
\hline \multirow{2}{*}{ Component } & \multicolumn{3}{|c|}{ Initial eigenvalues } & \multicolumn{3}{|c|}{ Sum of squares of extraction loads } \\
\hline & All & $\%$ of dispersions & Cumulative \% & All & $\%$ of dispersions & Cumulative \% \\
\hline 1 & 5.477 & 49.791 & 49.791 & 5.477 & 49.791 & 49.791 \\
\hline 2 & 1.848 & 16.800 & 66.591 & - & - & - \\
\hline 3 & 1.253 & 11.391 & 77.982 & - & - & - \\
\hline 4 & 0.983 & 8.941 & 86.923 & - & - & - \\
\hline 5 & 0.755 & 6.865 & 93.788 & - & - & - \\
\hline 6 & 0.354 & 3.220 & 97.008 & - & - & - \\
\hline 7 & 0.188 & 1.712 & 98.721 & - & - & - \\
\hline 8 & 0.101 & 0.918 & 99.639 & - & - & - \\
\hline 9 & 0.018 & 0.164 & 99.803 & - & - & - \\
\hline 10 & 0.016 & 0.147 & 99.950 & - & - & - \\
\hline 11 & 0.005 & 0.050 & 100.000 & - & - & - \\
\hline
\end{tabular}

Note: extraction method: principal component analysis.

Table 3. Matrix of components (component matrix (a))

Source: Calculated by the authors on the basis of data from the Main Directorates of Statistics in Dnipropetrovsk, Zaporizhzhia, Poltava, Sumy, Kharkiv regions (n.d.).

\begin{tabular}{|c|c|c|c|}
\hline Component & Value & Component & Value \\
\hline$x 1$ & 0.906 & $x 7$ & 0.819 \\
\hline$x 2$ & 0.893 & $x 8$ & 0.153 \\
\hline$x 3$ & -0.524 & $x 9$ & 0.266 \\
\hline$x 4$ & 0.941 & $x 10$ & 0.250 \\
\hline$x 5$ & -0.552 & $x 11$ & 0.801 \\
\hline$x 6$ & 0.962 & & \\
\hline
\end{tabular}

Note: extraction method: principal component analysis.

Table 4. Total dispersion that is explained by the first main component (Total Variance Explained)

Source: Calculated by the authors on the basis of data from the Main Directorates of Statistics in Dnipropetrovsk, Zaporizhzhia, Poltava, Sumy, Kharkiv regions (n.d.).

\begin{tabular}{c|c|c|c|c|c|c}
\hline \multirow{3}{*}{ Component } & \multicolumn{5}{c|}{ Initial eigenvalues } & $\begin{array}{c}\text { Sum of squares of extraction } \\
\text { loads }\end{array}$ \\
\cline { 2 - 7 } & All & $\begin{array}{c}\text { \% of } \\
\text { dispersions }\end{array}$ & Cumulative \% & All & $\begin{array}{c}\text { \% of } \\
\text { dispersions }\end{array}$ & Cumulative \% \\
\hline 1 & 4.248 & 60.693 & 60.693 & 4.248 & 60.693 & 60.693 \\
\hline 2 & 1.659 & 23.704 & 84.396 & - & - & - \\
\hline 3 & 0.734 & 10.491 & 94.888 & - & - & - \\
\hline 4 & 0.244 & 3.481 & 98.369 & - & - & - \\
\hline 5 & 0.077 & 1.106 & 99.475 & - & - & - \\
\hline 6 & 0.028 & 0.402 & 99.877 & - & - & - \\
\hline 7 & 0.009 & 0.123 & 100.000 & - & - & - \\
\hline
\end{tabular}

Note: extraction method: principal component analysis.

Table 5. Matrix of components (component matrix (a))

Source: Calculated by the authors on the basis of data from the Main Directorates of Statistics in Dnipropetrovsk, Zaporizhzhia, Poltava, Sumy, Kharkiv regions (n.d.).

\begin{tabular}{ccc}
\hline Component & Value & 0.054 \\
\hline$u 1$ & $u 2$ & 0.669 \\
$u 3$ & 0.706 & -0.888 \\
$u 4$ & -0.919 \\
$u 5$ & -0.886 \\
$u 6$ & -0.938 \\
\hline
\end{tabular}


that in 2017 and 2018, the leader in social and environmental development was Kharkiv region $(7.84,8.29)$, and in 2013-2015, Sumy region, where the highest value of the generalized indicator was 7.32, 7.73, 7.94, 7.28, respectively. The Dnipropetrovsk region has the least value of the generalized indicator of the level of social and environmental development, indicates a high level of man-made load in the region, which leads to a high level of morbidity and deterioration in the quality of life of the population.

According to the integral indicator "Economic Development Level", a model was constructed:

$$
\begin{aligned}
& X_{\tilde{X}_{e}}=0.91 \tilde{X}_{1 i j}+0.89 \tilde{X}_{2 i j}-0.52 \tilde{X}_{3 i j}+ \\
& +0.94 \tilde{X}_{4 i j}-0.55 \tilde{X}_{5 i j}+0.96 \tilde{X}_{6 i j}+ \\
& +0.82 \tilde{X}_{7 i j}+0.15 \tilde{X}_{8 i j}+0.27 \tilde{X}_{9 i j}+ \\
& +0.25 \tilde{X}_{10 i j}+0.8 \tilde{X}_{11 i j},
\end{aligned}
$$

where $X_{\tilde{X}_{e}}$ - integral index of level of economic development, $X_{n i j}$ - the initial statistical indicators of the $n$-th factor, which characterizes the level of economic development of the $i$-th region in the $j$-th period.

The result of calculating the integral indicator is the ranking of regions by the level of economic development, which is represented in the dynamics (Figure 1). The most stable positions have been observed for seven years in the Dnipropetrovsk region, and the lowest positions are in the Sumy region.

According to the integral indicator "The level of social and environmental development" of industrial regions of Ukraine in 2010-2016, a model was constructed:

$$
\begin{aligned}
& Y_{\tilde{U}_{e}}=0.54 \tilde{U}_{1 i j}+0.67 \tilde{U}_{2 i j}+0.71 \tilde{U}_{3 i j}- \\
& -0.89 \tilde{U}_{4 i j}-0.92 \tilde{U}_{5 i j}-0.89 \tilde{U}_{6 i j}-0.94 \tilde{U}_{7 i j},
\end{aligned}
$$

where $Y_{\tilde{U}}$ - integral index of level of socio-ecological development, $U_{n i j}$ - initial statistical indicators of the $n$-factor, which characterizes the level of socio-ecological development of the $i$-th region in the $j$-th period.

According to the results of calculations, it should be noted that the increase in the morbidity of the population due to excessive emissions of harmful substances, growth of the volume of waste and emissions of pollutants into the air leads to a decrease in the level of socio-ecological development of the region. The result of the calculation of the integral indicator is the ranking of regions by the level of socio-ecological development, which is represented in the dynamics (Figure 2). For this indicator during the analyzed period, the Sumy region occupies the leading position, and the lowest indicators are observed in the Dnipropetrovsk region.

Source: Developed by the authors based on Department of Statistics in Dnipropetrovsk, Zaporizhzhia, Poltava, Sumy, Kharkiv regions (2012-2018).

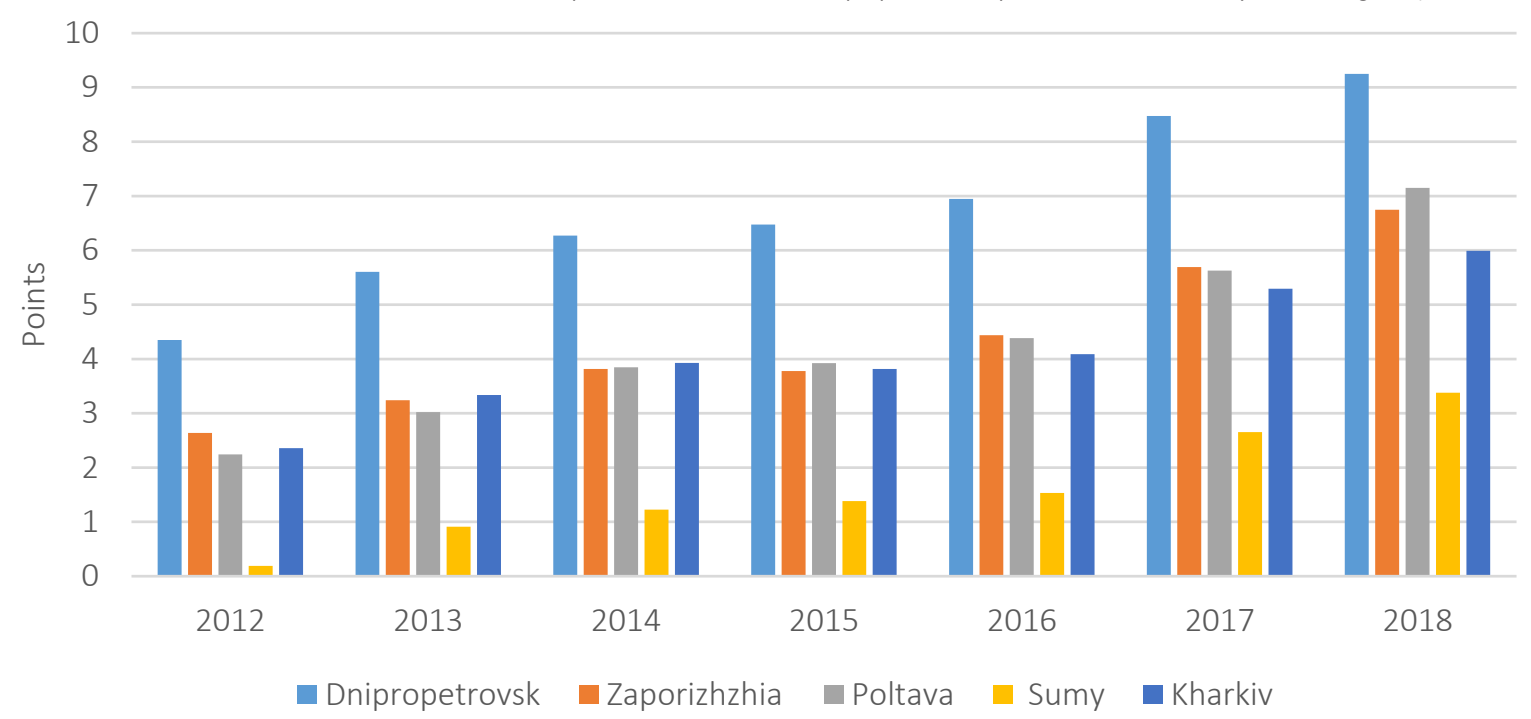

Figure 1. Integral index of level of economic development of regions 


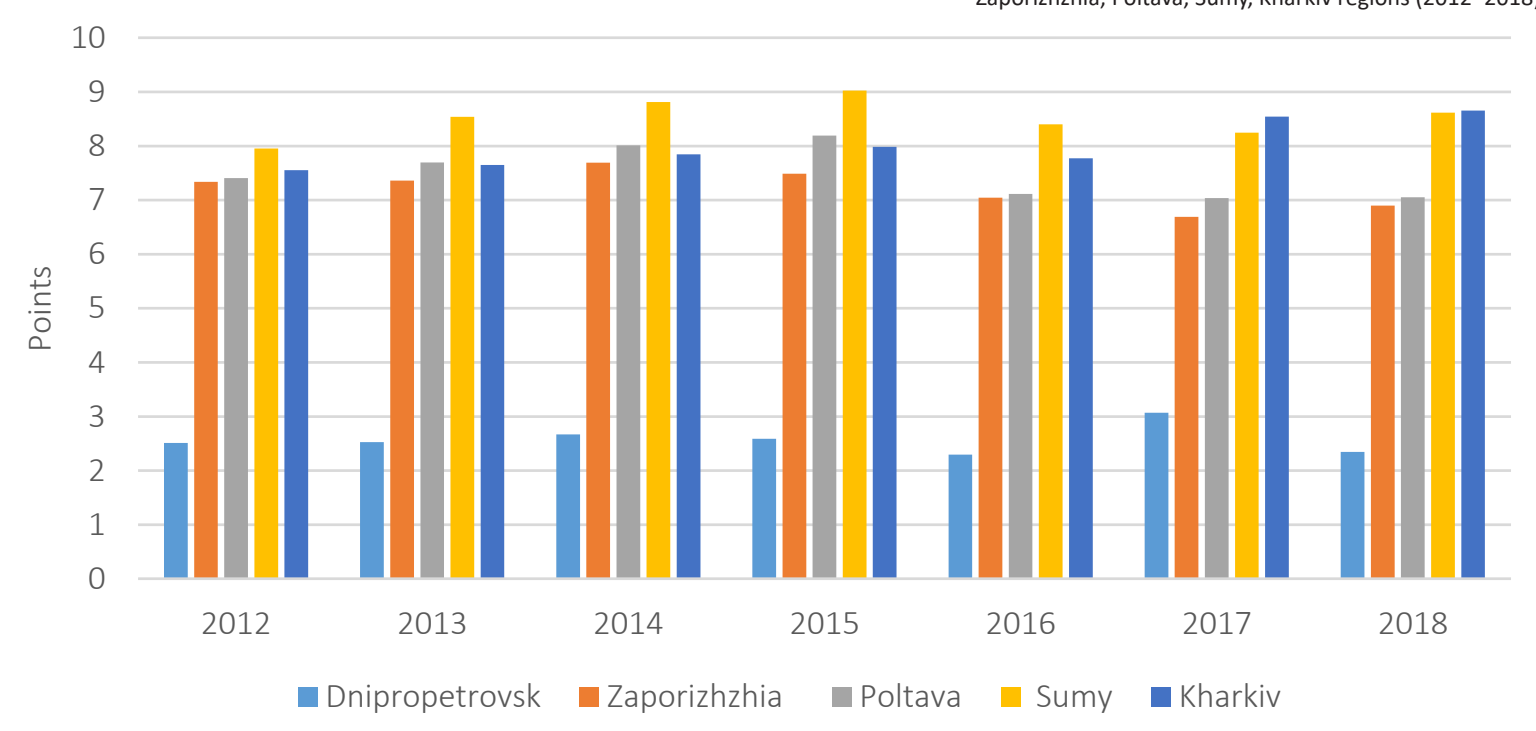

Figure 2. Integral index of level of socio-ecological development of regions

As a result, a generalized indicator of socioecological and economic development of industrial regions of Ukraine is calculated. According to the generalized indicator "The level of socio-ecological and economic development" of industrial regions of Ukraine in 2012-2018, a model was constructed (Figure 3):

$$
\begin{aligned}
& Z_{\tilde{X} \tilde{U}_{e}}=0.34 \tilde{X}_{1 i j}+0.20 \tilde{X}_{2 i j}+0.37 \tilde{X}_{3 i j}+ \\
& +0.67 \tilde{X}_{4 i j}+0.91 \tilde{X}_{5 i j}+0.65 \tilde{X}_{6 i j}+ \\
& +0.47 \tilde{X}_{7 i j}-0.14 \tilde{X}_{8 i j}-0.21 \tilde{X}_{9 i j}+ \\
& +0.26 \tilde{X}_{10 i j}-0.05 \tilde{X}_{11 i j}-0.02 \tilde{U}_{12 i j}+ \\
& +0.29 \tilde{U}_{13 i j}+0.27 \tilde{U}_{14 i j}-0.75 \tilde{U}_{15 i j}- \\
& -0.95 \tilde{U}_{16 i j}-0.89 \tilde{U}_{17 i j}-0.92 \tilde{U}_{18 i j},
\end{aligned}
$$

where $Z_{\tilde{X} \tilde{U}_{e}}$ - generalized indicator of the level of socio-ecological and economic development, $X_{n i j}, U_{n i j}-$ initial statistical indicators of the $n$-factor, which characterizes the level of socioecological and economic development of the $i$-th region in the $j$-th period.

Here should be noted the factors such as agricultural and construction indices, population incomes, low average monthly wages, population morbidity, total amount of waste and emissions of pollutants, including in the atmospheric air. The calculations of generalized integrated indices of development of industrial regions make it possible to determine the tendencies of sustainable development of separate regions according to the spheres of development and to substantiate promising directions of effective growth and areas which require the greatest attention from the state authorities and local selfgovernment bodies. By results it can be determined that serious problems of the Dnipropetrovsk region arise precisely because of the ecological component, which negatively affects the state of health and, consequently, quality of life.

The influence of ecological factors on the dynamics of the generalized indicator of sustainable development of regions was investigated and a forecast model for 2020-2024 for the analyzed industrial regions of Ukraine was constructed, which, with 95\% reliability, is adequate to the observations of the Fisher criterion and can be used for calculating the forecast values of the indicators:

$K_{1 U p}=3.98-0.366 \cdot U_{1 i j}+0.17 \cdot U_{2 i j}$

where $K_{1 U p}$ - forecast value of the generalized indicator of the level of socio-ecological and economic development of the regions, $U_{1 i j}-$ total amount of waste, tons per 1 person in the $i$-th region in the $j$-th period, $U_{2 i j}$ - emission of pollutants into the air from stationary sources of pollution, tons per 1 person in the $i$-th region in the $j$-th period. 


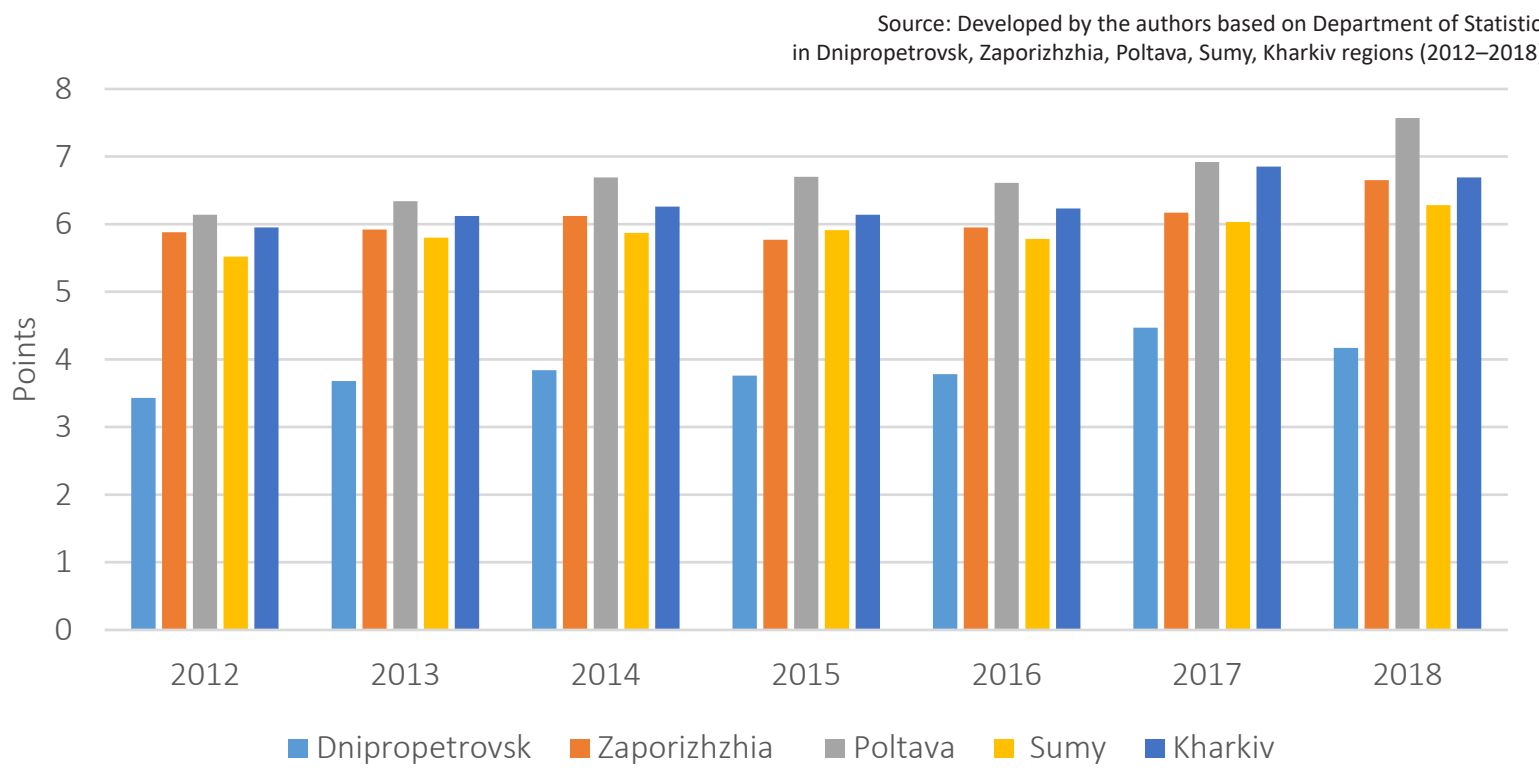

Figure 3. Integral index of level of socio-ecological development of regions

According to the results of the forecast model, there is a decrease in the forecast value of the indicator of the level of socio-ecological and economic development, which negatively affects the ranking of industrial regions. The growth of total waste in the regions is observed due to the lack of their utilization, which poses a threat to the health of the population and security of Ukraine. It is recommended to introduce the process of waste recycling and disposal as an effective means to improve the ecological situation in the regions and, consequently, to increase their level of socio-ecological and economic development.

A new model has been constructed, according to which the forecast values of the generalized indicator of the level of socio-ecological and economic development of the regions reflect the annual growth in the dynamics of the rating on the 10-point scale compared with the base year 2016 (Table 6):

$$
\begin{aligned}
& K_{2 U p}=2.35+0.066 \cdot U+ \\
& +0.15 \cdot U_{2 i j}+0.12 C_{1 i j},
\end{aligned}
$$

where $K_{2 U p}$ - forecast value of the general indicator of the level of socio-ecological and economic development of regions after the introduction of recycling and waste management, $C_{1 i j}$ - total waste after recycling and utilization, tons per 1 person in the region in the $j$-th period.

So, it should be noted that in all areas (Table 6), the growth of predicted values of the generalized indicator is increasing. The predicted values of the integral indicator reflect the annual growth in the dynamics of the rating on the 10-point scale compared with the base year 2018, which indicates the need to improve the environmental component of sustainable development of the regions.

In the case of expansion of the statistical base for the assessment of the region's development, the proposed methodology allows unlimited increase of the number of analyzed basic indicators.

Table 6. Predictions of the generalized indicator of the level of socio-ecological and economic development of regions

Source: Developed by the authors based on the of results prognosis model (n.d.).

\begin{tabular}{c|c|c|c|c|c}
\hline Years & Dnipropetrovsk & Zaporizhzhia & Poltava & Sumy & Kharkiv \\
\hline 2020 & 4,2812 & 6,467 & 7,422 & 6,256 & 6,764 \\
\hline 2021 & 4,3392 & 6,567 & 7,591 & 6,348 \\
\hline 2022 & 4,3924 & 6,666 & 7,774 & 6,448 & 6,875 \\
2023 & 4,4529 & 6,766 & 7,951 & 7,534 & 7,098 \\
2024 & 4,5085 & 6,866 & 8,133 & 7,209 \\
\hline
\end{tabular}




\section{CONCLUSION}

A methodical approach to assessing the level and trends of sustainable development of the region has been proposed. The approach is based on using the integral index. The evaluation and analysis results can be used to discuss problems and are implemented in the process of making sound management decisions. This approach by the factor analysis method allowed, based on the quantitative data from the State Statistics Service of Ukraine and the main statistics departments in the regions, to formulate a refined system of indicators that characterize economic, social and environmental sustainability parameters. Typical groups of regions of Ukraine were selected and an assessment of the level of socioecological and economic development was carried out (for example, five industrial regions, namely Dnipropetrovsk, Zaporizhzhia, Kharkiv, Poltava, Sumy). This made it possible, based on the procedures for reducing the dimension and constructing generalized indicators, to calculate the rating for each calculated integral indicator as a generalized estimate. The integral indicator allowed to determine the ranking of industrial regions by the level of information provision of socio-ecological and economic potential. This was done in order to identify areas for the distribution of innovation and information resources and to reduce the disproportions in the overall regional development, as well as coherence in the development of socio-cultural and environmental potential with the economic dynamics of the regions.

The calculations that have been carried out make it possible to determine the trends of sustainable development of individual regions according to development factors, as well as justify prospective directions for effective growth and negative tendencies, which require the greatest attention from the state authorities and local municipality. It was found that the most important problems of industrial regions arise precisely because of environmental factors that negatively affect the health and quality of life, respectively.

The proposed methodological approach can be used in the development and implementation of strategies for sustainable development of regions and in the process of regional development management in order to increase the efficiency of decision-making at the level of regional, local state administrations and local self-government bodies.

\section{REFERENCES}

1. Boyko, T., Chukhay, A., Dmytriuk, N., Goncharenko, I., Kovalenko, V., \& Podvysotska, T. (2012). Ukrainian National Competitiveness Report 2012. Foundation for Effective Governance. Retrieved from http:// www.feg.org.ua/uploadfiles/ckfinder/files/reports/2012/FEG_report_2012_ENG.pdf

2. Center of humanitarian technologies. Expert-analytical portal (n.d.). The rating of the world's crimes with the level of the gross domestic product to the soul of the population. Retrieved from http://gtmarket.ru/ratings/ratingcountries-gdp/rating-countriesgdp-info

3. Dept. of Political Coordination and Sustainable Development of the United Nations (n.d.). Global Sustainable Development Goals. Retrieved from http://un.org.ua/ua/

4. European Commission (n.d.) Energy union and climate. Retrieved from http://ec.europa.eu/

5. Global Innovation Index (2018). The World's Top Innovations 2018. Retrieved from https://www. globalinnovationindex.org/gii2018-report

6. Grechko, T., Lisovsky, S., Romanyuk, S., \& Rudenko, L. (2015). Публічне управління в забезпеченні сталого (збалансованого) розвитку [Publichne upravlinnia $v$ zabezpechenni staloho (zbalansovanoho) roz- vytku] (264 p.). Kherson: Grin D.S. https://igu.org.ua/uk/node/22049

7. Ilchenko, V. (2013). Аналіз показників сталості соціо-еколого-економічного розвитку регіону [Analiz pokaznykiv stalosti sotsioekoloho-ekonomichnoho rozvytku rehionu]. Visnyk sotsialno-ekonomichnykh doslidzhen, 2(2), 148-153. Retrieved from http://www.irbisnbuv.gov.ua/cgi-bin/irbis_nbuv/ cgiirbis_64.exe?I21DBN=LINK\&P2 $1 \mathrm{DBN}=\mathrm{UJRN} \& Z 21 \mathrm{ID}=\& \mathrm{~S} 21 \mathrm{REF}=$ $10 \& S 21 \mathrm{CNR}=20 \& S 21 \mathrm{STN}=1 \& S 21$ $\mathrm{FMT}=\mathrm{ASP}$-meta\&C21COM=S\&2 S21P03 $=$ FILA $=\& 2$ S21S TR=Vsed_2013_2\%282\%29_24

8. Ilchenko, V. (2018). Improvement of the mechanism of sustainable development of the region (280 p.). Kyiv. 
9. Lisovsky, S. A. (2009). Society and Nature: Balance of Interests on the Territory of Ukraine (300 p.). Institute of Geography, National Academy of Sciences of Ukraine.

10. Main Department of Statistics in Poltava region (n.d.). (2012-2018). Retrieved from http://pl.ukrstat. gov.ua/

11. Main Department of Statistics in Sumy region (n.d.). (2012-2018). Retrieved from http://sumy.ukrstat. gov.ual

12. Main Department of Statistics in the Dnipropetrovsk region (n.d.). (2012-2018). Retrieved from http://dneprstat.gov.ua/

13. Main Department of Statistics in the Kharkiv region (n.d.). (20122018). Retrieved from http:// kh.ukrstat.gov.ua/

14. Main Department of Statistics in Zaporizhzhia region (n.d.). (2012-2018). Retrieved from http://zp.ukrstat.gov.ua/

15. OECD (2018). Green growth and sustainable development: report. Retrieved from http://www.oecd.org/
16. Sadovenko, A., Maslovska, L., Sereda, V., \& Timochko, T. (2011) Індикатори сталого розвитку в Україні [Indykatory staloho rozvytku v Ukraini]. In Сталий розвиток суспільства [Stalyi rozvytok suspilstva] (pp. 245-250). Kyiv.

17. Social and Economic Council (SER) (2011). Development through sustainable enterprise. The Social and Economic Council Report. Retrieved from http://www.louiseofresco.nl/HTML/UK_PUBreports_ SER_Sustainable_enterprise.html

18. Subject.com.ua (2016). Education for sustainable development. National report. Retrieved from https://subject.com.ua/ecology/ conservation/3069.html

19. UN (1996). Indicators of Sustainable Development, UN Publication. Retrieved from https:// sustainabledevelopment.un.org/ content/documents/indisd-mg2001. pdf

20. UN Ukraine (2017). Sustainable Development Goals: Ukraine 2017. Retrieved from http://www. un.org.ua/ua/2017
21. UNEP (n.d.). Frontiers 2018/19: Emerging Issues of Environmental Concern. Retrieved from http:// web.unep.org/ru

22. World Bank (2018). World Bank Annual Report 2018. Retrieved from http://www.worldbank.org/ en/about/annual-report

23. Zgurovsky, M. (2009). Strong development of the regions of Ukraine (197 p.). Retrieved from http://wdc.org.ua/uk/node/39553

24. Zgurovsky, M. (Ed.) (2012). Analysis of Sustainable Development: Global and Regional Contexts (232 p.). International Science Council (ICSU), Ukraine in indicators of sustainable development (2011-2012).

25. Zhadko, K., \& Goryaschenko, Y. (2014). Діагностика регіонального розвитку за допомогою статистичного моніторингу та контролю [Diahnostyka rehionalnoho rozvytku za dopomohoiu statystychnoho monitorynhu ta kontroliu]. Aktualni problemy ekonomiky, 5(155), 485-490. Retrieved from https://eco-science. net/downloads/ 